\title{
Tekanan Penduduk Terhadap Lahan Pertanian di DAS Sembung, Kabupaten Sleman, DIY
}

\author{
${ }^{1}$ Gina Aprila Wangge, ${ }^{1}$ Arum Sari Widiastuti, ${ }^{1}$ Deka Ayu Maretya, ${ }^{1}$ Amalya Suci, ${ }^{1}$ Afid Nurkholis, ${ }^{1}$ Yuli \\ Widyaningsih, ${ }^{1}$ Ayu Dyah Rahma, ${ }^{1}$ Ardian Abdillah \\ ${ }^{1}$ Departemen Geografi Lingkungan, Fakultas Geografi, Universitas Gadjah Mada \\ email author: ginaaprilawangge@gmail.com
}

\begin{abstract}
Abstrak
Tekanan penduduk terhadap lahan adalah perbandingan antara jumlah penduduk dengan luas lahan minimal untuk dapat hidup layak. Perluasan fisik kota memiliki dampak negatif yang salah satunya tidak efektifnya pembangunan fasilitas pelayan kota dan ketidaksesuaian lahan sebagaimana mestinya. DAS Sembung memiliki lokasi yang strategis untuk dilakukan pembangunan karena letaknya yang berada di lereng kaki dan dataran kaki dari Gunugapi Merapi. Oleh karena itu, penelitian mengenai pengaruh tekanan penduduk terhadap lahan pertanian perlu dilakukan. Hasil perhitungan Tekanan Penduduk terhadap Lahan pada bentuklahan lereng kaki gunungapi adalah 0,14. Nilai tersebut menggambarkan bahwa hasil pertanian yang ada di lereng kaki masih mencukupi kebutuhan pangan penduduknya dengan luas lahan pertanian pada tahun 2014 sebesar 3.285.702,27 $\mathrm{m}^{2}$. Sementara itu, pada bentuklahan dataran kaki gunungapi diperoleh hasil sebesar 0,24. Hal tersebut juga menunjukkan bahwa pada bentuklahan ini belum terjadi tekanan penduduk terhadap lahan pertanian. Tekanan Penduduk terhadap Lahan Pertanian di DAS Sembung menunjukkan bahwa pada bentuklahan lereng kaki, dataran kaki, dan teras sungai tergolong rendah. Namun, nilai Tekanan Penduduk terhadap Lahan Pertanian pada dataran kaki lebih besar dari nilai Tekanan Penduduk pada lereng kaki karena lahan yang ada sudah termanfaatkan atau terbangun.
\end{abstract}

kata kunci: tekanan penduduk, lahan pertanian, DAS Sembung, Kabupaten Sleman

\section{$\underline{\text { Sitasi model APA }}$}

Wangge, G. A., Widiastuti, A. S., Maretya, D. A., Suci, A., Nurkholis, A., Widyaningsih, Y., Rahma, A. D., Abdillah, A. 2016. Tekanan Penduduk Terhadap Lahan Pertanian di DAS Sembung, Kabupaten Sleman, DIY. http://doi.org/10.17605/OSF.IO/EDAHR 


\section{PENDAHULUAN}

Tekanan penduduk terhadap lahan adalah perbandingan antara jumlah penduduk dengan luas lahan minimal untuk dapat hidup layak (Soemarwoto, 1985). Pengelolaan lahan sering menyebabkan terjadinya permasalahan yang berkaitan dengan pembangunan, para pembangun ingin terus membangun yang menandakan kemajuan pembangunan namun berkaitan dengan daya dukung lahan tentu hal ini akan menjadi masalah. Berdasarkan nilai lahan, terdapat faktor-faktor yang memepengaruhi yaitu (i) kualitas fisik lahan, (ii) lokasi lahan terhadap pasar hasil-hasil produksi dan pasar sarana produksinya, dan (iii) interaksi di antara keduanya (Soemarno, 2007).

DAS Sembung memiliki lokasi yang strategis untuk dilakukan pembangunan karena letaknya yang berada di lereng kaki dan dataran kaki dari Gunugapi Merapi (Gambar 2.1). Secara realtif, DAS Sembung berada disekitar Kampus UII (Universitas Islam Indonesia) dan sekitar wilayah Maguwharjo. Hal ini menyebabkan wilayah DAS Sembung menjadi sasaran pembangunan permukiman seperti yang diilustrasikan pada Gambar 1.1.

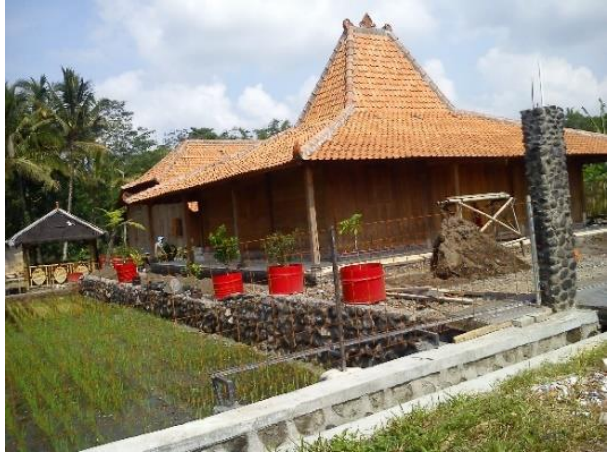

Villa di bagian hulu

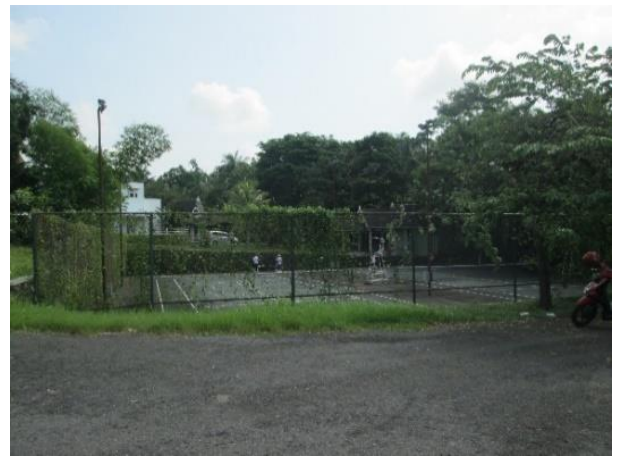

Lapangan tenis di lingkungan perumahan

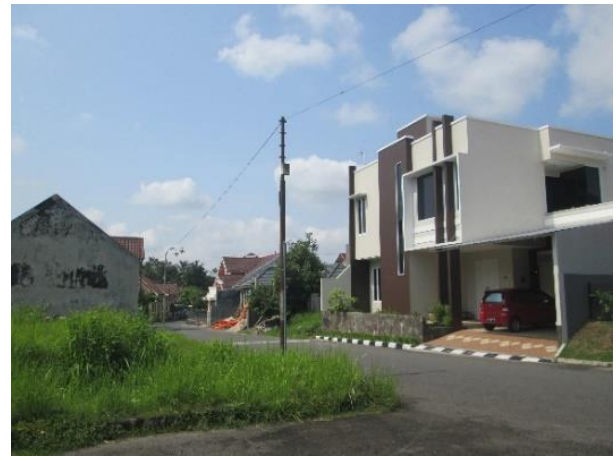

Perumahan di bagian dataran kaki

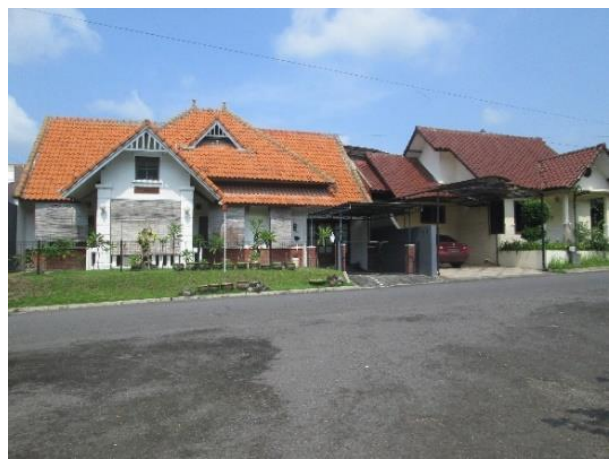

Permukiman di dataran kaki

Gambar 1.1. Konversi Penggunaan Lahan di DAS Sembung 
Permukiman merupakan kegiatan yang banyak mendominasi kegunaan lahan baik di kota maupun daerah pinggiran. Menjamurnya pembangunan permukiman yang ada di pinggiran kota secara tidak teratur mengakibatkan perkembangan kota disebut sebagai urban sprawl (Troy, 1996). Urban sprawl atau perluasan fisik kota memiliki dampak negatif yang salah satunya tidak efektifnya pembangunan fasilitas pelayan kota dan ketidaksesuaian lahan sebagaimana mestinya. Dalam merumuskan tata ruang kota dimasa yang akan datang. Yunus (2005) berpendapat bahwa pemahaman karakteristik fisik kota diperlukan guna menghindari dampak negatif dari perkembangan kota. Pemanfaatan lahan untuk permukiman harus diatur dengan baik sehingga sesuai dengan rencana tata ruang kota dan mempertimbangkan keseimbangan aspek ekologis sehingga tidak sampai terjadi penurunan kualitas lahan.

\section{WILAYAH KAJIAN}

DAS Sembung merupakan bagian dari DAS Opak. DAS Sembung dibagi menjadi tiga zonasi yaitu hulu, tengah, dan hilir. Penutup lahan yang dominan di DAS Sembung yaitu sebagai pertanian, perkebunan, dan permukiman. Klasifikasi lereng di DAS Sembung berupa lereng yag datar dan landai. Formasi batuan yang terdapat pada DAS Sembung berupa Qmi/ Qvu3 yaitu Endapan Volkanik Merapi Muda yang terdiri dari tuff, abu, breksi, aglomerat, dan leleran lava tak terpisahkan. Formasi ini berhulu pada Gunungapi Merapi dan menyusun sebagian besar lereng Gunung Merapi. Formasi berumur kuarter dan masih terus mengalami proses erupsi. Material yang tersusun merupakan hasil dari akumulasi erupsi Gunung Merapi. DAS Sembung memiliki tiga bentuklahan, yaitu lereng kaki volkanik, dataran kaki volkanik, dan teras sungai (Gambar 2.1).

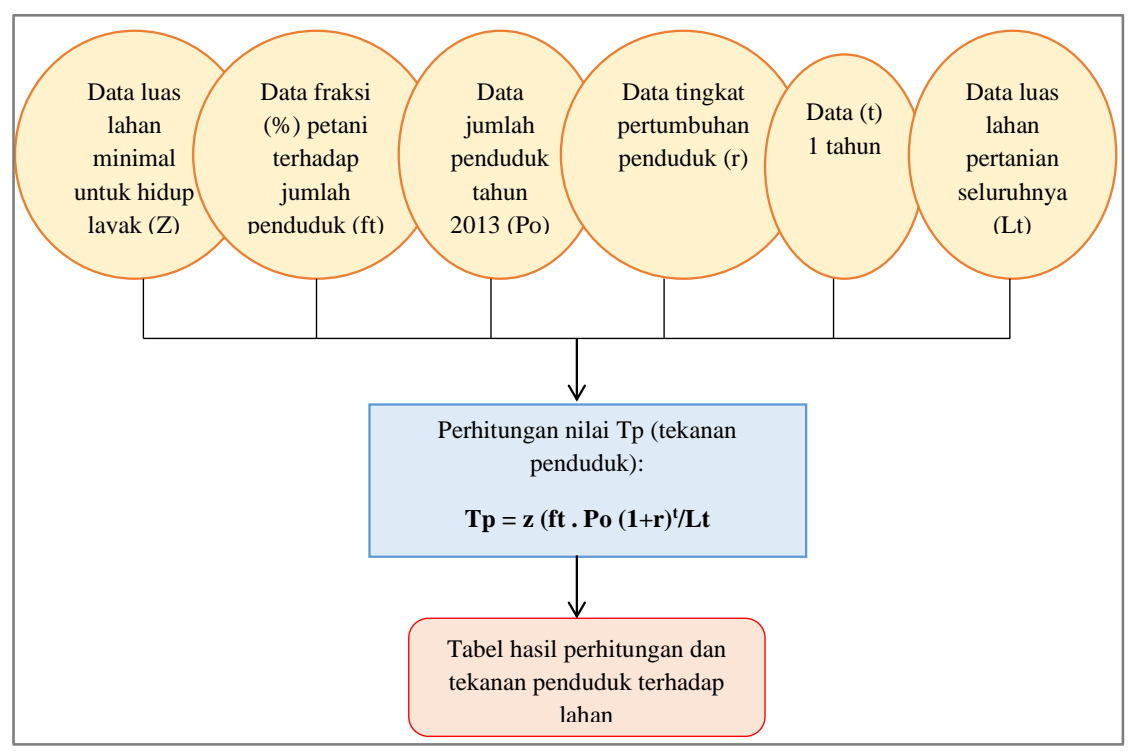

Gambar 3.1. Perhitungan Tekanan Penduduk Terhadap Lahan 


\section{METODE PENELITIAN}

Analisa kepadatan penduduk perlu dilakukan untuk mengetahui sejauh mana tingkat ketergantungan penduduk terhadap lahan di wilayah itu. Nilai kepadatan penduduk akan menjadi pertimbangan dalam penentuan arahan pemanfaatan lahan. Semakin tinggi tekanan penduduk maka pemanfaatan lahan semakin berorientasi pada pemenuhan kebutuhan hidup dan pelestarian sumberdaya lahan. Analisis ini disajikan pada Gambar 3.1.

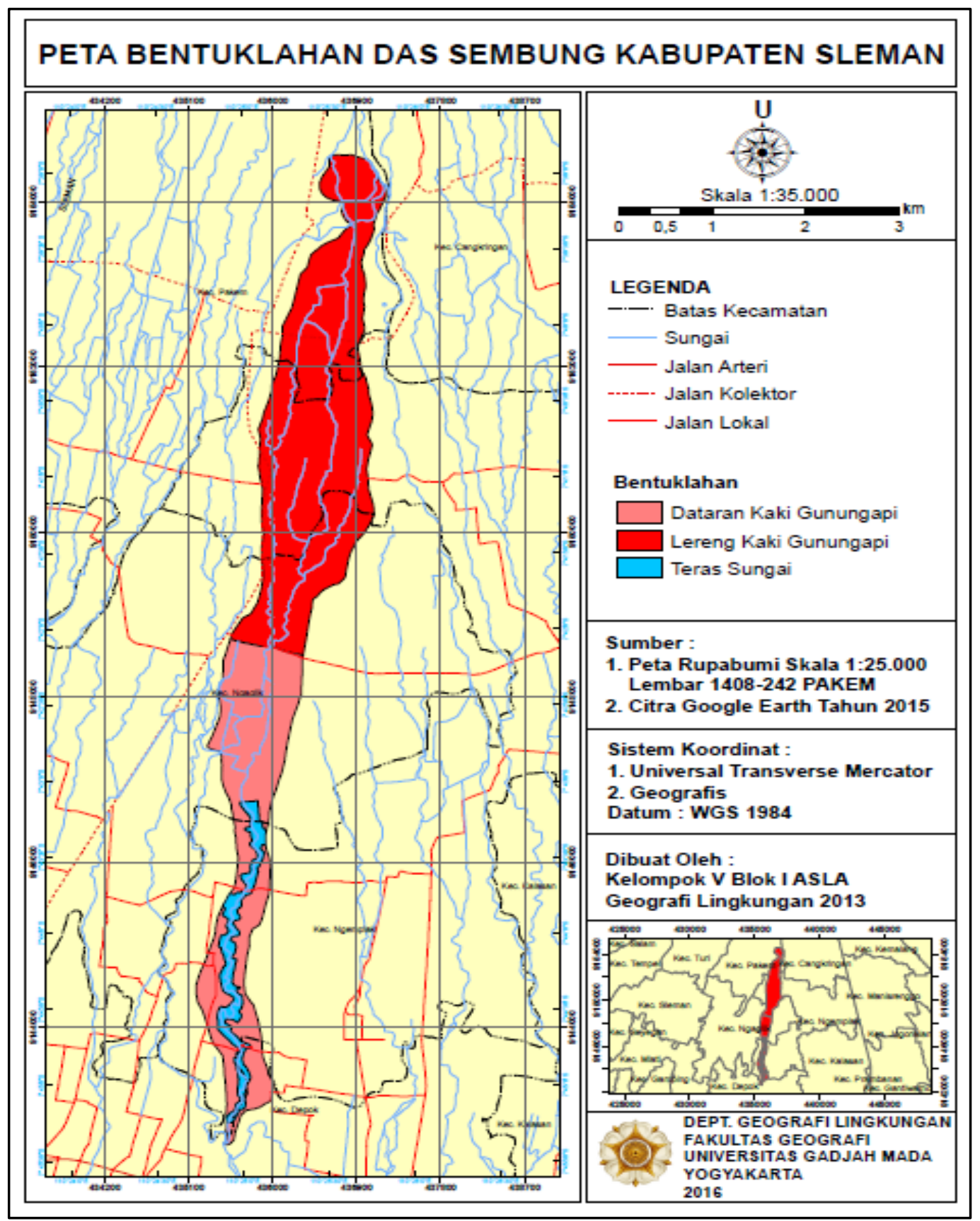

Gambar 2.1. Peta Bentuklahan DAS Sembung 


\section{HASIL DAN PEMBAHASAN}

Lahan pertanian yang ada di DAS Sembung masih tergolong luas daripada luas lahan yang digunakan untuk permukiman penduduk. Hasil perhitungan tekanan penduduk terhadap lahan pertanian di DAS Sembung pada bentuklahan lereng kaki gunungapi dan pada bentuklahan dataran kaki gunungapi tidak terlalu jauh berbeda (Tabel 4.1 dan 4.2)

Indeks Tekanan Penduduk terhadap Lahan Pertanian pada bentuklahan lereng kaki gunungapi yang meliputi sebagian Desa Pakembinangun, Desa Umbulmartani, Desa Sardonoharjo, dan sebagian Desa Sukoharjo adalah sebesar 0,14. Hal tersebut menunjukkan bahwa pada lereng kaki gunungapi belum terjadi tekanan penduduk terhadap lahan pertanian dan masih mampu memenuhi kebutuhan hidup penduduknya dalam jumlah penduduk yang berlebihan.

Tabel 4.1. Tekanan Penduduk Terhadap Lahan Pertaniaan di Lereng Kaki

\begin{tabular}{|c|c|c|c|c|c|c|c|c|c|c|c|c|}
\hline 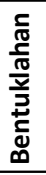 & $\begin{array}{l}\tilde{\coprod} \\
\text { ̊̆ }\end{array}$ & $\mathbf{P}$ & $\mathrm{ft}$ & LSI2 & LSI1 & ST & LLK & Z & Po & $\mathrm{Ft}$ & Lt & TK \\
\hline \multirow{4}{*}{ 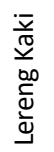 } & Pakembinangun & 2438,17 & 44,78 & \multirow{4}{*}{0} & \multirow{4}{*}{3219712,9} & \multirow{4}{*}{0} & \multirow{4}{*}{65989,35} & \multirow{4}{*}{0,51} & \multirow{4}{*}{12497} & \multirow{4}{*}{72,46} & \multirow{4}{*}{3285702,27} & \multirow{4}{*}{0,14} \\
\hline & Umbulmartani & 2610,16 & 55,49 & & & & & & & & & \\
\hline & Sardonoharjo & 612,59 & 0,10 & & & & & & & & & \\
\hline & Sukoharjo & 6835,98 & 0,00 & & & & & & & & & \\
\hline
\end{tabular}

Tabel 4.2. Tekanan Penduduk Terhadap Lahan Pertaniaan di Dataran Kaki

\begin{tabular}{|c|c|c|c|c|c|c|c|c|c|c|c|c|}
\hline 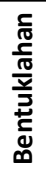 & $\begin{array}{l}\check{\Xi} \\
\text { 口̆ }\end{array}$ & $\mathbf{P}$ & $\mathrm{ft}$ & LSI2 & LSI1 & ST & LLK & $\mathbf{z}$ & Po & $\mathrm{Ft}$ & Lt & TK \\
\hline \multirow{5}{*}{$\begin{array}{l}\frac{\bar{v}}{\sqrt{\pi}} \\
\frac{1}{0} \\
\frac{\pi}{0} \\
\frac{\pi}{\pi} \\
0\end{array}$} & Sukoharjo & 6835,98 & 0,00 & \multirow{5}{*}{0} & \multirow{5}{*}{1413057,6} & \multirow{5}{*}{0} & \multirow{5}{*}{96869,11} & \multirow{5}{*}{0,52} & \multirow{5}{*}{11644} & \multirow{5}{*}{58,82} & \multirow{5}{*}{1509926,69} & \multirow{5}{*}{0,24} \\
\hline & Wedomartani & 2825,97 & 43,75 & & & & & & & & & \\
\hline & Sinduharjo & 1390,51 & 0,14 & & & & & & & & & \\
\hline & Condongcatur & 17,94 & 0,14 & & & & & & & & & \\
\hline & Maguwoharjo & 573,40 & 14,78 & & & & & & & & & \\
\hline
\end{tabular}

Hasil perhitungan Z (luas lahan minimal untuk dapat hidup layak) yang diperoleh melalui berbagai parameter luasan lahan yaitu luas lahan sawah 1x panen (LSII) adalah 3.219.712,92 dan luas sawah tadah hujan (ST) adalah nol, hal tersebut disebabkan karena pendekatan yang digunakan untuk menghitung luasan lahan pertanian tersebut adalah menggunakan hasil digitasi pada peta sehingga didapati luasan LSI1 dan keakuratan data tergantung pada orang yang menginterpretasi penggunaan lahan yang ada di lereng kaki gunungapi Merapi. Pendekatan tersebut digunakan karena batasan yang digunakan adalah batasan DAS yang tidak bertampalan dengan batas administrasi desa, sehingga terdapat kesulitan menentukan luasan lahan pertanian dengan menggunakan data yang ada yaitu Data Kecamatan dalam Angka tahun 2014. 
Hasil perhitungan Tekanan Penduduk terhadap Lahan pada bentuklahan lereng kaki gunungapi adalah 0,14. Nilai tersebut menggambarkan bahwa hasil pertanian yang ada di lereng kaki masih mencukupi kebutuhan pangan penduduknya dengan luas lahan pertanian pada tahun 2014 sebesar 3.285.702,27 $\mathrm{m}^{2}$. Kondisi nyata di lapangan menunjukkan bahwa jumlah permukiman yang ada di bentuklahan lereng kaki memang belum terlalu banyak, sehingga indeks tekanan penduduk terhadap lahan pertanian yang ada masih tergolong rendah. Presentasi petani di dalam bentuklahan lereng kaki gunungapi cukup tinggi yakni sebesar 72,46\%, hal tersebut ditandai pula dengan banyaknya lahan pertanian dan banyaknya petani yang dijumpai pada saat survey lapangan dilakukan. Petani-petani yang ada lebih banyak menggarap lahan sebagai lahan sawah yang ditanami sepanjang tahun. Melimpahnya air yang berasal dari mata air, saluran irigasi, dan sungai mendukung penggunaan lahan sebagai lahan persawahan $\left({ }^{1}\right.$ Nurkholis, dkk, 2016).

Perhitungan Z (luas lahan minimal untuk dapat hidup layak) pada bentuklahan dataran kaki gunungapi sebesar 0,52 ha/orang. Parameter yang digunakan untuk menghitung nilai z pada dataran kaki sama dengan parameter yang digunakan pada lereng kaki gunungapi. Pendekatan yang digunakan untuk menghitung luasan setiap lahan pertanian sama yakni pendekatan batasan DAS yang tidak selalu bertampalan dengan batas administrasi sehingga menggunakan hasil digitasi dari citra untuk menentukan luasan masing-masing lahan pertanian.

Perhitungan Indeks Tekanan Penduduk terhadap Lahan Pertanian pada bentuklahan dataran kaki gunungapi diperoleh hasil sebesar 0,24. Hal tersebut juga menunjukkan bahwa pada bentuklahan ini belum terjadi tekanan penduduk terhadap lahan pertanian. Indeks Tekanan Penduduk terhadap Lahan Pertanian antara lereng kaki dengan dataran kaki tidak jauh berbeda, hanya berbeda angka 0,1 . Hal tersebut disebabkan karena bentuklahan dataran kaki yang masuk ke dalam DAS Sembung luasnya lebih kecil dibandingkan bentuklahan lereng kaki gunungapi sehingga luas lahan pertanian yang digunakan untuk menghitung $\mathrm{Z}$ juga lebih sedikit. Jumlah penduduk yang berada di dataran kaki juga lebih sedikit, faktor-faktor tersebut yang menyebabkan Indeks Tekanan Penduduk terhadap Lahan Pertanian pada dataran kaki.

Secara umum, kedua bentuklahan pada DAS Sembung belum mengalami tekanan penduduk terhadap lahan pertanian (Gambar 4.1). Kondisi tersebut dibuktikan dengan masih luas dan produktifnya lahan-lahan pertanian yang berada di lereng kaki maupun di dataran kaki berdasarkan hasil digitasi, interpretasi citra, dan survei lapangan yang telah dilakukan. Penggunaan lahan selain pertanian yang berada di dalam DAS Sembung masih relatif sedikit, yakni hanya 
berupa permukiman. Permukiman yang ada masih jarang sehingga alih fungsi lahan yang ada masih tergolong rendah. Meskipun demikian, beberapa wilayah telah mengalami alih fungai luhan menjadi permukiman dan perumahan (Gambar 4.2)

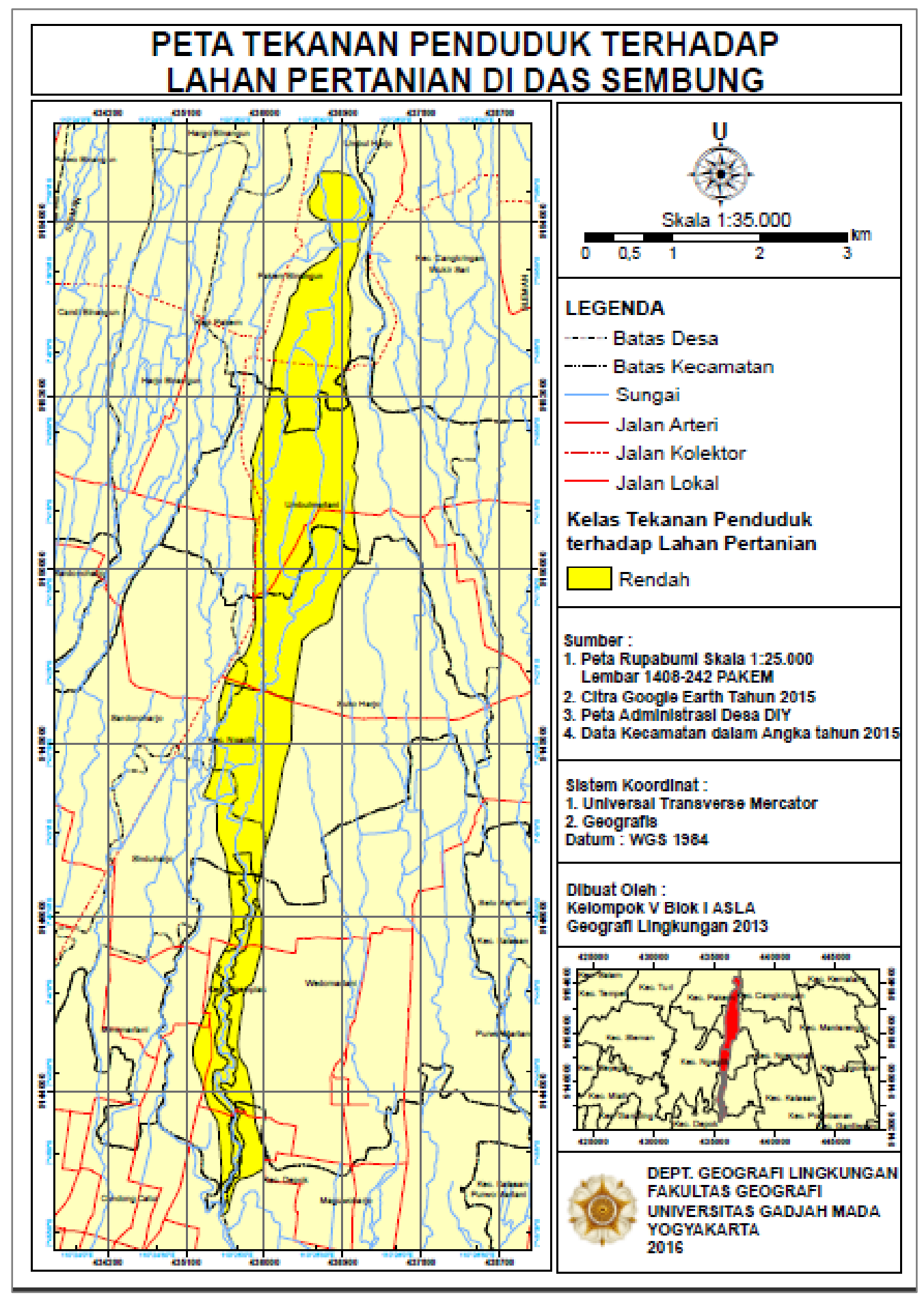

Gambar 4.1. Peta Tekanan Penduduk Terhadap Lahan Pertanian di DAS Sembung 
Tabel 4.3. menunjukkan hubungan antara kelas kemampuan lahan dengan tekanan penduduk terhadap lahan pertanian untuk menentukan potensi degradasi lahan. Potensi degradasi lahan pada DAS Sembung tergolong rendah pada bentuklahan lereng kaki dan dataran kaki, hal ini disebabkan karena kelas kemampuan lahan pada bentuklahan ini tergolong kelas $1\left({ }^{2}\right.$ Nurkholis, dkk, 2016). Potensi degradasi lahan masih rendah pada dua bentuklahan ini disebabkan karena kondisi lahan yang ada masih cukup alami.

Penggunaan lahan yang ada masih sesuai dengan kemampuan lahan dan belum tentu eksploitatif. Berbeda dengan kondisi potensi degradasi lahan pada bentuklahan teras sungai yang dikategorikan tinggi berdasarkan hasil penentuan kelas kemampuan lahannya. Hal tersebut disebabkan karena pada teras sungai selalu terusik dengan ancaman banjir yang senantiasa terjadi pada saat hujan turun sehingga bentuklahan teras sungai ini memiliki potensi degradasi lahan yang tinggi.

Tabel 4.3 Hubungan kelas kemampuan lahan, tekanan penduduk terhadap lahan dan potensi degradasi lahan

\begin{tabular}{|c|c|c|c|}
\hline \multicolumn{1}{|r|}{$\begin{array}{l}\text { Tekanan Penduduk } \\
\text { Terhadap Lahan } \\
\text { Kemampuan } \\
\text { Lahan }\end{array}$} & Kelas 1 (TP < 1) & Kelas 2 (TP=1) & Kelas 3 (TP>1) \\
\hline I & & & \\
\hline II & PDR & PDR & PDR \\
\hline III & PDR & PDR & PDR \\
\hline IV & PDR & PDS & PDS \\
\hline V & PDS & PDS & PDS \\
\hline VI & PDS & PDS & PDT \\
\hline VII & PDT & PDT & PDT \\
\hline VIII & PDT & PDT & PDT \\
\hline
\end{tabular}

Keterangan : PDR : Potensi degradasi lahan rendah

PDS : Potensi degradasi lahan sedang

PDT : Potensi degradasi lahan tinggi

Lahan-lahan yang berada di dalam DAS ini masih produktif dan digunakan berdasarkan kemampuan lahan yang sesuai.Lahan-lahan pertanian yang ada subur karena berada pada satuan 
bentuklahan lereng kaki gunungapi dan dataran kaki gunungapi Merapi sehingga senantiasa mendapatkan material yang mempunyai kandungan mineral dan zat hara tinggi. Kondisi alami tersebut sangat mendukung pertumbuhan tanaman atau komoditas tertentu dapat tumbuh subur pada lahan-lahan yang ada. Lahan-lahan yang ada dominan merupakan lahan pertanian sawah irigasi dengan kesempatan panen dalam setahun $>2$ kali. Kondisi lahan yang ditanami secara terus menerus tanpa adanya masa bero menyebabkan dalam jangka waktu yang panjang degradasi atau kerusakan lahan tidak bisa dihindarkan. Oleh karena itu, sangat diperlukan suatu analisis daya dukung lingkungan yang menunjukkan seberapa besar kemampuan lingkungan mendukung kehidupan penduduk yang berada di DAS Sembung.

\section{KESIMPULAN}

Tekanan Penduduk terhadap Lahan pada bentuklahan lereng kaki gunungapi adalah 0,14. Nilai tersebut menggambarkan bahwa hasil pertanian yang ada di lereng kaki masih mencukupi kebutuhan pangan penduduknya dengan luas lahan pertanian pada tahun 2014 sebesar 3.285.702,27 $\mathrm{m}^{2}$. Sementara itu, pada bentuklahan dataran kaki gunungapi diperoleh hasil sebesar 0,24. Hal tersebut juga menunjukkan bahwa pada bentuklahan ini belum terjadi tekanan penduduk terhadap lahan pertanian. Tekanan Penduduk terhadap Lahan Pertanian di DAS Sembung menunjukkan bahwa pada bentuklahan lereng kaki, dataran kaki, dan teras sungai tergolong rendah. Namun, nilai Tekanan Penduduk terhadap Lahan Pertanian pada dataran kaki lebih besar dari nilai Tekanan Penduduk pada lereng kaki karena lahan yang ada sudah termanfaatkan atau terbangun.

\section{DAFTAR PUSTAKA}

${ }^{1}$ Nurkholis, A., Widyaningsih, Y., Rahma, A. D., Suci, A., Abdillah, A., Wangge, G. A., Widiastuti, A. S., Maretya, D. A. 2016. Analisis Neraca Air DAS Sembung, Kabupaten Sleman, DIY (Ketersediaan Air, Kebutuhan Air, Kekritisan Air). http://doi.org/10.17605/OSF.IO/YMHKG

${ }^{2}$ Nurkholis, A., Widyaningsih, Y., Rahma, A. D., Suci, A., Abdillah, A., Wangge, G. A., Widiastuti, A. S., Maretya, D. A. 2016. Analisis Kemampuan Dan Kesesuaian Lahan di DAS Sembung, Kabupaten Sleman, DIY. http://doi.org/10.17605/OSF.IO/M9DKN

Soemarwoto, O., 1985. A Qualitative of Population Pressure and It's Potential Use in Development Planning. Majalah Demografi Indonesia, 12 (24) 
Soemarno, M.S. 2007. Risiko Penggunaan Lahan dan Analisisnya Laboratorium PPJP Jurusan Tanah. Malang : FPUB

Troy, Patrick N. 1996. The Perils of Urban Consolidation. Federation Press, Sydney

Yunus, Hadi Sabari. 2005. Manajemen Kota. Yogyakarta: Pustaka Pelajar 